\section{Genetic variability for osmotic adjustment in pollen grains and its association with field tolerance to moisture stress in maize inbred lines}

\section{S. Ashwini, N. Chandrakala and \\ R. L. Ravikumar*}

Department of Plant Biotechnology, University of Agricultural Sciences, GKVK, Bengaluru 560 065, India

Drought severely affects gametophytic development in maize. To explore pollen tolerance to drought stress, the pollen grains of 16 inbred lines were subjected to osmotic stress (without and with osmolyte; $10 \mathrm{mM}$ $\mathrm{CaCl}_{2}$ ) under in vitro conditions. The effect of stress was observed as a measure of intrinsic osmotic adjustment (OA) and induced OA. Evaluation of inbreds for drought tolerance in field indicated significant differences for sensitivity drought index (SDI) among the lines. The $\Delta^{13}$ surrogate trait indicated genotypic differences for drought tolerance. Significant negative correlation was observed between pollen OA and SDI values; and positive correlation between pollen $\mathrm{OA}$ and $\Delta^{13}$ values, suggesting correspondence in drought tolerance between pollen and sporophyte. The superoxide dismutase isozyme expression also indicated the overlap drought tolerance mechanism. Thus, the present study provides an insight into overlapping behaviour regarding stress response mechanism of pollen grains and plants.

Keywords: Drought tolerance, gametophytic selection, osmotic adjustment, maize.

MAIZE is a major crop cultivated worldwide and highly productive under optimal environment and crop management conditions. However, maize plants are highly susceptible to drought and moisture stress because yield losses are up to $90 \%$ when it occurs at reproductive stage $^{1-4}$. Drought tolerance can be accomplished through development of moisture stress tolerant genotypes. Tolerance to drought is a complex character and difficult to screen the genotypes due to genotypes $\times$ environmental interactions. Therefore, an alternative technique like estimating water use efficiency (WUE) which relies on long term measurement of plant water consumption was also proposed ${ }^{5}$. A complementary selection strategy to rapidly identify high performing yield components in water deficient crop plants, $\Delta^{13}$ as an indirect indicator of WUE has been proposed ${ }^{6,7}$. However these large scale approaches are not feasible in individual plants screening efforts ${ }^{8,9}$ in plant breeding.

Reproductive development in higher plants is known to be very sensitive to abiotic stress which results in lower

\footnotetext{
*For correspondence. (e-mail: rlravikumar@rediffmail.com)
}

seed set in most crops ${ }^{10,11}$. During male reproductive development, the young microspore is known to be highly sensitive to abiotic stress ${ }^{12,13}$. It was also reported that the in vivo viability, germination of pollen grains and the number of pollen grains reaching the ovary is also significantly reduced under moisture stress ${ }^{14}$. In vitro culture of pollen grains have shown that the pollen grains and pollen tube are very sensitive to osmotic changes in the medium $^{15,16}$. At the whole plant level as well, plant cells accumulate different types of organic and inorganic solutes in the cytosol to lower osmotic potential, thereby maintaining cell turgor in response to improving water uptake $^{17,18}$. The process of accumulation of organic solutes such as amino acids, glycerol, sucrose, lower molecular weight metabolites ${ }^{19}$ and inorganic ions mainly $\mathrm{Na}^{+}, \mathrm{K}^{+}, \mathrm{Ca}^{2+}$ and $\mathrm{Cl}^{-}$serve as a function to balance the osmotic potential in cells under osmotic stress ${ }^{20}$. Pollen grains, upon hyperosmolar shock, modulate the plasma membrane $\mathrm{H}^{+}$ATPase activity. Consequently, the more negative membrane potential allows a higher ions influx that in turn promotes water uptake to readjust the turgor pressure $^{21,22}$. Thus the osmotic adjustment taking place in pollen grains by adapting the turgor pressure under stress could be used for genotype screening for moisture stress tolerance. Male gametophytic screening as a non-invasive technique for various biotic and abiotic stress tolerance has been proposed in many crop plants ${ }^{15,23-25}$. In this study, an attempt has been made to measure the pollen osmotic adjustment (OA) and compare with drought susceptibility maize inbred lines, under field conditions. Considering that it is generally difficult to find a singular plant trait responsive for drought stress tolerance and yield advantage under drought stress conditions, this evidence will be a remarkable proof that pollen OA sustains crop yield under drought stress.

Sixteen homozygous maize inbred lines, viz. BTM1, ВТМ2, ВTM4, ВТМ5, ВТМ6, ВТМ7, ВТМ8, ВТМ10, BTM13, BTM14, BTM15, BTM 18, BTM 19, HT1, DT3 and MAI105 specifically developed for abiotic stress tolerance were selected for the study ${ }^{26}$. The fresh pollen grains of inbred lines collected from the field grown plants in the morning hours (8-9 a.m.) were exposed to osmotic stress by incubating the pollen grains in $50 \%$ PEG-6000 solution. Further to study the response of pollen grains to osmolyte, the 50\% PEG solution was supplemented with $10 \mathrm{mM} \mathrm{CaCl}_{2}$ (refs 27, 28). The pollen grains were incubated in $50 \mu \mathrm{l}$ of $50 \%$ PEG and $50 \%$ PEG $+10 \mathrm{mM} \mathrm{CaCl}_{2}$ solution in cavity slides for $24 \mathrm{~h}$ at $70-80 \%$ RH under room temperature. For each inbred line and treatment, four cavities were prepared.

The size of the pollen grains was measured after $24 \mathrm{~h}$ using a compound microscope with a projection screen at a magnification of $400 \times$. The circumference of the pollen grains on the screen was recorded using inbuilt software (Imagefocus v3.0). For each treatment 20 pollen grains were randomly selected from each cavity to record 
observations. The normal size of the pollen grains (control) was measured immediately after dispersing the pollen grains into distilled water in cavity slides.

The following pollen parameters were determined for all the genotypes according to Patil and Ravikumar ${ }^{28}$.

Normal size of the pollen grains (A): The size of the pollen grains measured immediately after dispensing into distilled water.

Effect of osmotic stress on pollen grains (B): The pollen grain size dispensed in 50\% PEG solution measured after $24 \mathrm{~h}$.

Response to osmolyte $(\mathrm{C})$ : The pollen grain size dispensed in $50 \%$ PEG with $10 \mathrm{mM} \mathrm{CaCl}_{2}$ solution measured after $24 \mathrm{~h}$.

The ratio $\mathrm{B} / \mathrm{A}$ indicates intrinsic $\mathrm{OA}$ and $\mathrm{C} / \mathrm{A}$ indicates induced $\mathrm{OA}$ mechanism operating in pollen grains.

The sixteen inbred lines were grown following a split plot design with two main plot (stress and non-stress) and 16 sub-plot (inbred lines) treatments during summer 2016 in field conditions at GKVK, UAS, Bangalore. Each inbred line was grown in a single row of $3 \mathrm{~m}$ and two replications for each treatment. The stress environment was created by withdrawing water for 20 days starting from 45 th day after sowing. All the other agronomic practices were same for both the treatments.

Five plants per replication per treatment were selected for recording observations on cob length, cob diameter, number of rows per cob, number of kernels per row, number of seeds per cob, test weight and grain yield. Split plot design was used with moisture stress as main treatment and inbred lines as sub-plot for analysis of data. The sensitivity drought index (SDI) for each genotype was also determined for grain yield and yield related traits $^{29}$.

$$
\text { SDI }=\frac{\text { Value in irrigation }- \text { Value in stress }}{\text { Value in irrigation }} \times 100
$$

For carbon isotope discrimination analysis, unstressed seeds of all inbred lines were oven-dried at $80^{\circ} \mathrm{C}$ for $48 \mathrm{~h}$ and ground to a fine powder. Carbon isotope composition was determined on $1 \mathrm{mg}$ sample using Isotopic Ratio Mass Spectrometer (Model Thermo Finnigan, Bremen, Germany) situated at the University of Agricultural Sciences, Bangalore. Carbon isotope discrimination values $\left(\Delta^{13}\right)$ were estimated and calculated according to Monneveux et al. ${ }^{6}$.

To study the strength of relationship between pollen $\mathrm{OA}$ and plant tolerance to moisture stress, the association between pollen parameters $(\mathrm{B} / \mathrm{A}$ and $\mathrm{C} / \mathrm{A})$ and SDI for grain yield and yield components (cob length, cob diameter, number of rows per cob, number of kernels per row, number of seeds per cob and test weight) and $\Delta^{13}$ were determined using Spearman's rank correlation co-efficient ${ }^{30}$.
Equal quality of fresh pollen grains of the two inbred lines BTM1 (drought susceptible) and BTM2 (drought tolerant) were given the following treatments.

$\mathrm{T}_{1}$ : Fresh pollen collected on day of protein extraction.

$\mathrm{T}_{2}$ : Pollen grains incubated at $90 \% \mathrm{RH}$ for 24 hours.

$\mathrm{T}_{3}$ : Pollen grains incubated in $50 \%$ PEG solution for $24 \mathrm{~h}$.

$\mathrm{T}_{4}$ : Pollen grains incubated in $50 \%$ PEG $+10 \mathrm{mM}$ $\mathrm{CaCl}_{2}$ for $24 \mathrm{~h}$.

After incubation, the pollen grains in $\mathrm{T}_{3}$ and $\mathrm{T}_{4}$ were precipitated by centrifugation at $100 \mathrm{rpm}$ for $45 \mathrm{sec}$ and the supernatant was removed. The pollen grains were homogenized and the protein was isolated in phosphate buffer $\mathrm{pH} 7.8$ (ref. 31) and quantified ${ }^{32}$.

Protein isolation from plants: Two inbred lines were grown in pots till the 40th day with sufficient moisture ( $100 \%$ field capacity). On the 40th day, the inbred lines were subjected to two levels of stress by withholding water for 2 and 3 days respectively. The control plants were watered continuously. The leaf samples (3rd and 5th position from top) were used for isolation of total protein in phosphate buffer and quantified ${ }^{32}$.

Polyacrylamide gel electrophoresis and staining for superoxide dismutase (SOD) activity: SOD enzymes were separated by non-denaturing separating gels $(15 \%)$ at $4{ }^{\circ} \mathrm{C}$ and the gels were stained for SOD enzyme activity according to Fridovich ${ }^{33}$.

The ability of the crop plants to tolerate moisture stress is the main aspect of the crop stability and its improvement has always been a challenge to breeders. The plants have evolved a series of mechanisms at the morphological, physiological, biochemical and cellular levels to overcome water stress. Drought stress affects all the growth stages in plants from germination to grain filling and grain yield ${ }^{34}$. Maize, despite being an efficient water user, is badly affected by drought stress due to hypersensitivity against water deficiency ${ }^{35}$. The studies on maize plants indicated that the moisture stress had a significant effect at all the growth stages and the genotypes showed differential sensitivity to moisture stress ${ }^{36-39}$.

In the present study, the moisture stress treatment had significant effect on all the traits (Table 1) and there was a significant reduction in grain yield and important yield components in stress treatment (Table 2). SDI for seed yield, which is a direct indicator of yield loss under moisture stress ranged from $24.52 \%$ in BTM10 to $78.12 \%$ in BTM18. The inbred lines BTM1, BTM6, MAI105 and HT1 recorded significant reduction (higher SDI values) for grain yield and yield components indicating their susceptibility to moisture stress. On the other hand, the inbred lines BTM2, BTM4, BTM10, BTM13, BTM14 and BTM5 recorded lower SDI values for grain yield per plant and other traits under moisture stress indicating their tolerance. The genotypic difference to moisture stress tolerance has also been reported earlier ${ }^{40-42}$. The $\Delta^{13}$ values, a surrogate trait for moisture stress 
RESEARCH COMMUNICATIONS

Table 1. ANOVA for growth and yield traits of different maize inbred lines in well irrigated and stressed condition

\begin{tabular}{|c|c|c|c|c|}
\hline Source & Replication & Main plot (C) & Sub plot $(G)$ & $\mathrm{G} \times \mathrm{C}$ \\
\hline Cob length (cm) & 0.042 & $62.13 * *$ & $3.90 * *$ & $2.33^{* *}$ \\
\hline Cob diameter $(\mathrm{cm})$ & 0.062 & $4.72 * *$ & $0.25 * *$ & $0.12 * *$ \\
\hline No. of rows per cob & 2.49 & 821.89 & $46.60 * *$ & $11.68 * *$ \\
\hline No. of kernel per row & 0.55 & $364.06^{*}$ & $13.31 * *$ & $10.05 * *$ \\
\hline No. of seeds per cob & 20.62 & $608987.37 *$ & $15427.59 * *$ & $9669.89 * *$ \\
\hline Test weight $(\mathrm{g})$ & 0.091 & $271.67 *$ & $109.66^{* *}$ & $9.1 * *$ \\
\hline Grain yield per plant (g) & 32.87 & $48304.91 *$ & $1108.49 * *$ & $625.98 * *$ \\
\hline
\end{tabular}

** Significant at $1 \%$ probability level; *Significant at $5 \%$ probability level.

Table 2. Sensitivity drought index of yield parameters in well irrigated $(\mathrm{N})$ and stressed condition (S)

\begin{tabular}{|c|c|c|c|c|c|c|c|}
\hline Genotype & $\mathrm{CL}$ & DM & NOR & KR & NOS & TW & GY \\
\hline BTM 1 & $37.97 * *$ & $32.20 * *$ & $62.77 * *$ & $54.22 * *$ & $71.84 * *$ & $35.15 * *$ & $64.72 * *$ \\
\hline BTM 2 & 1.43 & 0.26 & 6.59 & 9.89 & 16.95 & 6.72 & 18.74 \\
\hline BTM 4 & $18.40 * *$ & $17.73 * *$ & $41.30 * *$ & $32.23 * *$ & $53.69 * *$ & $31.71 * *$ & 45.26 \\
\hline BTM 5 & 8.6 & $9.09 *$ & 5.22 & $30.00 * *$ & 45.09 & $16.97 * *$ & $34.51 * *$ \\
\hline BTM 6 & $14.88 * *$ & $17.47 * *$ & $34.60 * *$ & 18.68 & $34.34 * *$ & $12.54 * *$ & 45.43 \\
\hline BTM 7 & 3.8 & $16.32 * *$ & $37.09 * *$ & $43.93 * *$ & $79.35 * *$ & 1.51 & $68.81 * *$ \\
\hline ВТМ 8 & $13.54 * *$ & 7.14 & $40.14 * *$ & $15.88 * *$ & $38.64 * *$ & 6.38 & 31.77 \\
\hline ВТМ 10 & $28.08 * *$ & $17.36^{* *}$ & $40.82 * *$ & $25.26 * *$ & $45.15 * *$ & $38.71 * *$ & 24.52 \\
\hline ВTM 13 & $17.16^{*}$ & 7.73 & 23.34 & 5.82 & 27.61 & 10.76 & 25.33 \\
\hline BTM14 & 9.52 & 8.27 & 14.68 & $8.73 * *$ & 29.49 & 5.18 & 33.3 \\
\hline ВTM 15 & 10.13 & $16.99 * *$ & $37.42 * *$ & $38.96 * *$ & $75.49 * *$ & $23.68 * *$ & $61.25 * *$ \\
\hline ВТМ 18 & $31.54 *$ & $17.23 * *$ & $35.65 * *$ & $47.70 * *$ & 67.03 & 4.6 & $78.12 * *$ \\
\hline ВТМ 19 & $13.68 * *$ & 7.4 & $38.96 * *$ & 32.85 & $53.09 * *$ & $21.85 * *$ & 42.92 \\
\hline DT 3 & $26.51 * *$ & $9.34 * *$ & 26.44 & $14.49 * *$ & 43.39 & $15.55 * *$ & 49.13 \\
\hline MAI 105 & $32.00 *$ & $22.33 * *$ & 29.08 & 47.5 & $70.09 * *$ & $26.08 * *$ & $63.20 * *$ \\
\hline HT 1 & $22.06 * *$ & $20.00 * *$ & $31.58 * *$ & $49.15 * *$ & $57.00 * *$ & $15.80 * *$ & $63.62 * *$ \\
\hline CD@5\% & 1.6 & 0.32 & 9.12 & 3.36 & 108.61 & 2.61 & 42.97 \\
\hline CD@1\% & 2.03 & 0.41 & 8.5 & 3.78 & 116.75 & 3.06 & 42.67 \\
\hline
\end{tabular}

CL, Cob length; DM, Cob diameter; NOR, Number of rows per cob; KR, Number of kernels per row; NOS, Number of seeds per cob; TW, Test weight; YP, Grain yield per plant.

$* *$ Significant at $1 \%$ probability level; *Significant at $5 \%$ probability level.

Table 3. $\Delta^{13}$ values of maize inbred lines

\begin{tabular}{ll}
\hline Genotypes & $\Delta^{13}$ \\
\hline BTM1 & 2.77 \\
BTM2 & 2.90 \\
BTM4 & 2.40 \\
BTM5 & 1.55 \\
BTM6 & 1.52 \\
BTM7 & 2.09 \\
BTM8 & 2.12 \\
BTM10 & 2.80 \\
BTM13 & 1.97 \\
BTM14 & 2.71 \\
BTM15 & 1.92 \\
BTM18 & 1.65 \\
BTM19 & 2.57 \\
DT3 & 2.78 \\
MAI105 & 1.47 \\
HT1 & 1.92 \\
\hline
\end{tabular}

indicated difference among the inbred lines. The inbred lines BTM2, BTM10 and DT3 recorded high values while MAI105, BTM6 and BTM5 recorded low $\Delta^{13}$ values (Table 3).
The previous experiments support the hypothesis that the pollen expression and responses in the contrasting genotypes to moisture stress were found in the association of the sporophyte or plant response ${ }^{15,27,28,43,44}$. In the present study, 50\% PEG stress under in vitro conditions has reduced the size of the pollen grains of majority of the genotypes except BTM6 and BTM10 (Table 4 and Figure 1). Pollen mortality due to dehydration was observed as moisture of pollen is lost due to drying conditions ${ }^{45}$. The retention of size in two genotypes could be due to inherent tolerance by accumulation of higher concentrations of osmolytes as the osmolytes assist in maintaining the turgor pressure ${ }^{21,27}$. The two genotypes did not show significant grain yield reduction under moisture stress conditions in field level as well. The intrinsic OA adjustment observed in pollen grains and plant prevent the loss of the turgor and maintains the pollen grain size, physiological and biochemical activities of the plant cell under moisture stress conditions. The correspondence between the intrinsic $\mathrm{OA}$ in pollen and plant response to tolerate moisture stress has also been observed in wheat ${ }^{27}$ and sorghum $^{28}$. 

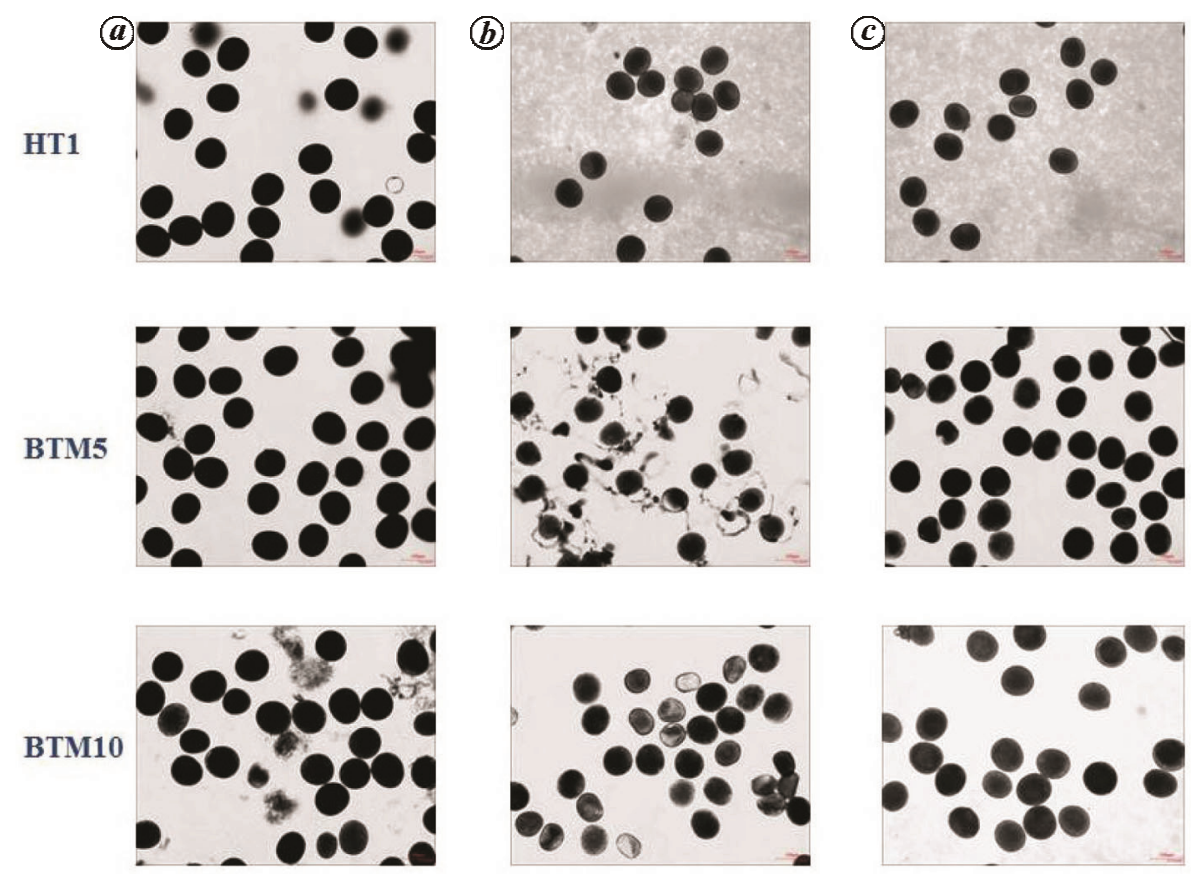

Figure 1. Effect of osmotic stress and osmolyte on size and shape of pollen grains (a, Control; $\boldsymbol{b}$, Pollen grains $50 \%$ PEG; $c$, Pollen grains 50\% PEG with $\mathrm{CaCl}_{2}$ ).

Table 4. Intrinsic $(\mathrm{B} / \mathrm{A})$ and induced osmotic adjustment $(\mathrm{C} / \mathrm{A})$ in pollen grains of maize inbred lines

\begin{tabular}{lll}
\hline & \multicolumn{2}{c}{$50 \%$ PEG } \\
\cline { 2 - 3 } Genotypes & B/A & C/A \\
\hline BTM1 & $0.67 * *$ & $0.79 * *$ \\
BTM2 & $0.67 * *$ & 0.97 \\
BTM4 & $0.79 * *$ & 0.93 \\
BTM5 & $0.53 * *$ & 0.99 \\
BTM6 & 0.98 & 0.98 \\
BTM7 & $0.63 * *$ & $0.88 *$ \\
BTM8 & $0.63 * *$ & 0.98 \\
BTM10 & 0.99 & 0.99 \\
BTM13 & $0.65 * *$ & 0.89 \\
BTM14 & $0.52 * *$ & 0.95 \\
BTM15 & $0.54 * *$ & $0.77 * *$ \\
BTM18 & $0.46 * *$ & $0.79 * *$ \\
BTM19 & $0.76 * *$ & $0.88^{* *}$ \\
DT3 & $0.70^{* *}$ & $0.89 *$ \\
MAI105 & $0.56 * *$ & $0.55 * *$ \\
HT1 & $0.47 * *$ & $0.49 * *$ \\
\hline
\end{tabular}

A, Control; B, 50\% PEG level; C, 50\% PEG $+\mathrm{CaCl}_{2}$.

**Significant at $1 \%$ probability level; *Significant at $5 \%$ probability level.

The pollen grains responded to supplemented osmolyte in the medium (Table 4 and Figure 1). The dependence of the pollen response to stress on calcium was also according to the expectations based on previous work on plant cell, tissue and pollen grains ${ }^{27,46,47}$. The pollen grain size increased with the supplementation of $10 \mathrm{mM} \mathrm{CaCl}_{2}$ over PEG alone. Upregulation of related genes and accumula- tion of osmolyte under moisture stress to protect the pollen grains through osmolytes was observed in plants ${ }^{48}$. The pollen grains responded to osmolyte $\mathrm{Ca}^{+}$and the inbred lines BTM5, BTM6, BTM8 and BTM10 regained their original size indicating operation of induced $\mathrm{OA}$ in these genotypes. The genotypic differences, high and low OA types have been observed in maize ${ }^{49}$.

The carbon isotope discrimination $\left(\Delta^{13}\right)$ is highly correlated with plant water use efficiency and the moisture stress tolerance ${ }^{50}$. Several recent studies have demonstrated that $\Delta^{13}$ may be used as surrogate to select for improved moisture tolerance in plants. The increase in the $\Delta^{13}$ values increases the moisture tolerance of plant and vice versa ${ }^{6,7}$. Both intrinsic $(\mathrm{B} / \mathrm{A})$ and induced $(\mathrm{C} / \mathrm{A})$ osmotic adjustment recorded positive correlation with $\Delta^{13}$ values in this study suggesting pollen OA can be used as an alternative method to select for improved moisture stress tolerance. Highly significant negative correlation was observed between induced pollen OA with SDI for grain yield and other important yield components like number of seeds per cob, number of kernels per row and cob diameter (Table 5). Higher intrinsic and particularly greater induced OA in pollen grains of maize inbred lines recorded significant association with sporophytic tolerance to moisture stress in maize inbred lines. The results clearly demonstrate the association between gametophytic and sporophytic tolerance to moisture stress in maize. Therefore, the induced pollen OA can be used as surrogate to select moisture stress tolerance ${ }^{27,28}$. The results provide further evidence of the expression of genes in the male gametophyte similar to sporophyte ${ }^{51}$; hence its 


\section{RESEARCH COMMUNICATIONS}

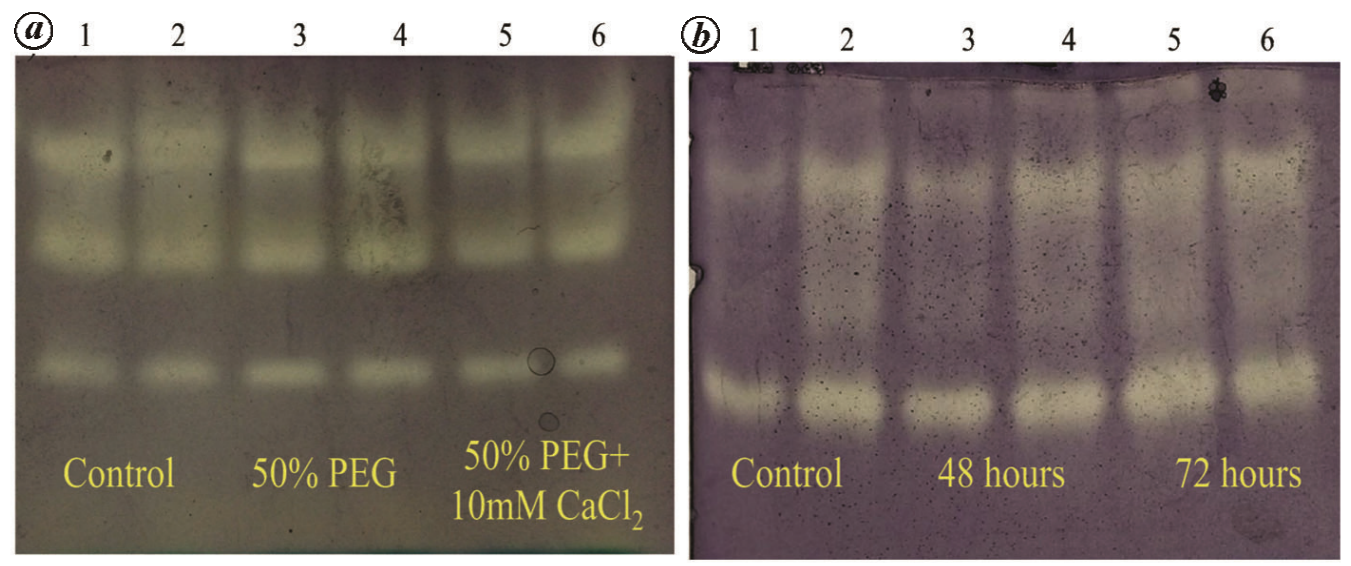

Figure 2. Superoxide dismutase isozyme banding pattern in stressed and control pollen grains and plant samples of maize. $\boldsymbol{a}$, Pollen grains; $\boldsymbol{b}$, Plant (lanes 1, 3, 5, BTM1; lanes 2, 4, 6, BTM2).

Table 5. Correlation between pollen parameters and sensitivity drought index of different plant traits

\begin{tabular}{lcl}
\hline Treatments/ parameters & $50 \mathrm{~B} / \mathrm{A}$ & $50 \mathrm{C} / \mathrm{A}$ \\
\hline Cob length & 0.14 & -0.37 \\
Cob diameter & 0.05 & $-0.63^{* *}$ \\
Number of rows per cob & $-0.42^{*}$ & -0.26 \\
Number of kernels per row & -0.26 & $-0.85^{* *}$ \\
Number of seeds per cob & -0.21 & $-0.85^{* *}$ \\
Test weight & $0.45^{*}$ & -0.22 \\
Grain yield per plant & -0.35 & $-0.86^{* *}$ \\
$\Delta^{13}$ & $0.44^{*}$ & $0.43^{*}$ \\
\hline
\end{tabular}

**Significant at $1 \%$ probability level; *Significant at $5 \%$ probability level.

utility in plant breeding ${ }^{52}$. The leaf osmotic adjustment has been shown as an important drought tolerance mechanism in many crop plants such as rice ${ }^{53,54}$, wheat ${ }^{55}$, sorghum $^{56}$ and maize ${ }^{57}$. Therefore, it is possible that pollen osmotic adjustment can be utilized as an alternate, easy and fast technique to identify drought tolerant genotypes in breeding.

The overlap of pollen and sporophytic behaviour and gene expression was studied by means of SOD enzyme electrophoresis. Of the three isozymes found, two were expressed in both gametophyte and sporophyte and the remaining band was specific to pollen and leaves (Figure 2). The estimated overlap of the common, sporophytic and gametophytic protein expression corresponds with the estimates obtained in other plant species ${ }^{58}$. The pollen responses are generally correlated to sporophytic behaviour $^{43,59}$. It was also observed that there is an increase in the intensity of the bands both in plants and pollen grains under stress in both the genotypes. Plants protect themselves from drought induced oxidative damage, through an array of anti-oxidative enzymes like SOD and others. Several reports underline a direct relationship between enhanced SOD enzyme activities and increased tolerance to environmental stresses ${ }^{60,61}$. Previously it has been shown that drought stress is linked to pollen sterility during the early reproductive stages ${ }^{62}$. Biochemically characterizing the link between reactive oxygen species metabolism, protective enzyme activity and plant and pollen tolerance would further increase our understanding in this area. In summary, this study provides an insight into the overlap in the mechanism of moisture stress tolerance in pollen grains and plants in maize.

1. Nesmith, D. S. and Ritchie, J. T., Effects of soil waterdeficits during tassel emergence on development and yield component of maize (Zea mays). Field Crops Res., 1992, 28(3), $251-256$.

2. Saini, H. S. and Westgate, M. E., Reproductive development in grain crops during drought. Adv. Agron., 1999, 68, 59-96.

3. Ghooshchi, F., Seilsepour, M. and Jafari, P., Effects of water stress on yield and some agronomic traits of maize [SC 301]. Am.-Eurasian J. Agric. Environ. Sci., 2008, 4(3), 302-305.

4. Molla, M. S. H., Nakasathien, S., Sarobol, E. and Vichukit, V., Effects of nitrogen and water on maize varieties under short and prolonged drought. J. Dev. Sustain. Agric., 2014, 9, 97-110.

5. Shah, N. H. and Paulsen, G. M., Response of wheat to combined high temperature and osmotic stresses during maturation 2: plant photosynthesis and productivity. Pak. J. Biol. Sci., 2000, 3(10), 1639-1643.

6. Monneveux, P., Sheshshayee, M. S., Akhter, J. and Ribaut, J., Using carbon isotope discrimination to select maize (Zea mays L.) inbred lines and hybrids for drought tolerance. Plant Sci., 2007, 173, 390-396.

7. Akhter, J., Monneveux, P., Sabir, S. A., Ashraf, M. Y., Lateef, Z. and Serraj, R., Selection of drought tolerant and high water use efficient rice cultivars through $13 \mathrm{C}$ isotope discrimination technique. Pak. J. Bot., 2010, 42(6), 3887-3897.

8. Blum, A., Effective use of water (EUW) and not water-use efficiency (WUE) is the target of crop yield improvement under drought stress. Field Crops Res., 2009, 112, 119-123.

9. Brito, G. G., Sofiatti, V., Lima, M. M., Carvalho, L. P. and Filho, J. L., Physiological traits for drought phenotyping in cotton. Acta Sci.-Agron., 2011, 33(1), 117-125.

10. Prasad, P. V. V., Boote, K. J., Thomas, J. M. G., Allen, L. H. and Gorbet, D. W., Influence of soil temperature on seedling emergence 
and early growth of peanut cultivars in field conditions.J. Agron. Crop Sci., 2006, 192, 168-177.

11. Oshino, T., Abiko, M., Saito, R., Ichiishi, E., Endo, M., Kawagishi-Kobayashi, M. and Higashitani, A., Premature progression of anther early developmental programs accompanied by comprehensive alterations in transcription during high temperature injury in barley plants. Mol. Genet. Genomics, 2007, 278, 31-42.

12. Oliver, S. N., Dennis, E. S. and Dolferus, R., ABA regulates apoplastic sugar transport and is a potential signal for coldinduced pollen sterility in rice. Plant Cell Physiol., 2007, 48, 1319-1330.

13. Barnabás, B., Jäger, K. and Fehér, A., The effect of drought and heat stress on reproductive processes in cereals. Plant Cell Environ., 2008, 31, 11-38.

14. Fan, L. M., Wang, Y. F., Wang, H. and Wu, W. H., In vitro Arabidopsis pollen germination and characterization of the inward potassium currents in Arabidopsis pollen grain protoplasts. J. Exp. Bot., 2001, 52, 1603-1614.

15. Ravikumar, R. L., Patil, B. S. and Salimath, P. M., Drought tolerance in sorghum by pollen selection using osmotic stress. Euphytica, 2003, 133, 371-376.

16. Totsky, I. V. and Lyakh, V. A., Pollen selection for drought tolerance in sunflower. Helia, 2015, 38(63), 211-220.

17. Rhodes, D. and Samaras, Y., Genetic control of osmoregulation in plants. In Cellular and Molecular Physiology of Cell Volume Regulation (ed. Strange, S. K.), CRC Press, Boca Raton, 1994, pp. 347-361.

18. Chen, H. and Jiang, J., Osmotic adjustment and plant adaptation to environmental changes related to drought and salinity. Environ. Rev., 2010, 18, 309-319.

19. Jakobsen, A. N., Aasen, I. M. and Strøm, A. R., Endogenously synthesized (-)-proto-quercitol and glycine betaine are principal compatible solutes of Schizochytrium sp. strain S8 (ATCC 20889) and three new isolates of phylogenetically related thraustochytrids. Appl. Environ. Microbiol., 2007, 73(18), 5848-5856.

20. Gagneul, D., Aïnouche, A., Duhazé, C., Lugan, R., Larher, F. R. and Bouchereau, A., A reassessment of the function of the so-called compatible solutes in the halophytic plumbaginaceae Limonium latifolium. Plant Physiol., 2007, 144(3), 1598-1611.

21. Holdaway-Clarke, T. L. and Hepler, P. K., Control of pollen tube growth: role of ion gradients and fluxes. New Phytol., 2003, 159 539-563.

22. Michard, E., Alves, F. and Feijó, J. A., The role of ion fluxes in polarized cell growth and morphogenesis: the pollen tube as an experimental paradigm. Int. J. Dev. Biol., 2009, 53, 1609-1622.

23. Koval, V. S., Male and female gametophyte selection of barley for salt tolerance. Hereditas, 2000, 132, 1-5.

24. Clarke, H. J., Khan, T. N. and Siddique, K. M. H., Pollen selection for chilling tolerance at hybridisation leads to improved chickpea cultivars. Euphytica, 2004, 139, 65-74.

25. Kakani, V. G., Reddy, K. R., Koti, S., Wallace, T. P., Prasad, P. V. V., Reddy, V. R. and Zhao, D., Differences in in vitro pollen germination and pollen tube growth of cotton cultivars in response to high temperature. Ann. Bot., 2004, 96, 59-67.

26. Singh, A., Ravikumar, R. L. and Jingade, P., Genetic variability for gametophytic heat tolerance in maize inbred lines. SABRAO J. Breed. Genet., 2016, 48(1), 41-49.

27. Morgan, J. M., Pollen grain expression of a gene controlling differences in osmoregulation in wheat leaves: a simple breeding method. Aust. J. Agric. Res., 1999, 50, 953-962.

28. Patil, B. S. and Ravikumar, R. L., Osmotic adjustment in pollen grains: a measure of drought adaptation in sorghum? Curr. Sci., 2011, 100(3), 377-382.

29. Farshadfar, E., Mohammadi, R., Farshadfar, M. and Shokouh, D., Relationships and repeatability of drought tolerance indices in wheat-rye disomic addition lines. Aust. J. Crop Sci., 2013, 7(1), $130-138$.
30. Siegel, S., Nonparametric Statistics for the Behavioural Sciences, McGraw-Hill Kogakusha, Ltd, Tokyo, 1956, p. 312.

31. Wang, W., Vignani, R., Scali, M. and Cresti, M., A universal and rapid protocol for protein extraction from recalcitrant plant tissues for proteomic analysis. Electrophoresis, 2006, 27, 2782-2786.

32. Lowry, O. H., Rosebrough, N. J., Farr, A. L. and Randall, R. J., Protein measurement with the Folin phenol reagent. J. Biol. Chem., 1951, 193, 265-275.

33. Fridovich, I., Superoxide dismutases. Adv. Enzymol. Relat. Areas Mol. Biol., 1986, 58, 61-97.

34. Farooq, M., Wahid, A., Kobayashi, N., Fujita, D. and Basra, S. M. A., Plant drought stress: effects, mechanisms and management. Agron. Sustain. Dev., 2009, 29, 185-212.

35. Aslam, M., Maqbool, M. A. and Cengiz, R., Drought Stress in Maize (Zea mays L.) Effects, Resistance Mechanisms, Global Achievements and Biological Strategies for Improvement, Springer, 2015, 5-17.

36. Pandey, R. K., Maranville, J. W. and Admou, A., Deficit irrigation and nitrogen effects on maize in a Sahelian environment: I. Grain yield and yield components. Agric. Water Manage., 2000, 46(1), $1-13$.

37. Payero, J. A., Melvin, S. B., Irmak, S. C. and Tarkalson, D., Yield response of corn to deficit irrigation in a semiarid climate. Agric. Water Manage., 2006, 84, 101-112.

38. Campos, H., Cooper, M., Habben, J. E., Edmeades, G. O. and Schussler, J. R., Improving drought tolerance in maize: a view from industry. Field Crops Res., 2004, 90, 19-34.

39. Cattivelli, L. et al., Drought tolerance improvement in crop plants: An integrated view from breeding to genomics. Field Crops Res., 2008, 105, 1-14.

40. Grzesiak, S., Genotypic variation between maize (Zea mays L.) single-cross hybrids in response to drought stress. Acta Physiol. Plant., 2001, 23(4), 443-456.

41. Olaoye, G., Bello, O. B., Abubakar, A. Y., Olayiwola, L. S. and Adesina, O. A., Analyses of moisture deficit grain yield loss in drought tolerant maize (Zea mays L.) germplasm accessions and its relationship with field performance. Afr. J. Biotechnol., 2009, 8(14), 3229-3238.

42. Ziyomo, C., Albrecht, K. A., Baker, J. M. and Bernardo, R., Corn performance under managed drought stress and in a kura clover living mulch intercropping system. Agron. J., 2013, 105(3), 579586.

43. Hormaza, J. I. and Herrero, M., Pollen selection. Theor. Appl. Genet., 1992, 83, 663-672.

44. Banica, C., Petcu, E., Giura, A. and Saulescu, N. N., Relationship between genetic differences in the capacity of osmotic adjustment and other physiological measures of drought resistance in winter wheat (Triticum aestivum L.). Rom. Agric. Res., 2008, 25, 7-11.

45. Aylor, D. E., Quantifying maize pollen movement in a maize canopy. Agric. For. Meteorol., 2005, 131, 247-256.

46. Gilliham, M. et al., Calcium delivery and storage in plant leaves: exploring the link with water flow. J. Exp. Bot., 2011, 62(7), 2233-2250.

47. Ahmad, P., Latef, A., Abd_Allah, E. F., Hashem, A., Sarwat, M., Anjum, N, A. and Gucel, S., Calcium and potassium supplementation enhanced growth, osmolyte secondary metabolite production and enzymatic antioxidant machinery in cadmium-exposed chickpea (Cicer arietinum L.). Front. Plant Sci., 2016, 7(513), 112.

48. Taji, T., Ohsumi, C., Iuchi, S., Seki, M., Kasuga, M., Kobayashi, M., Yamaguchi-Shinozaki, K. and Shinozaki, K., Important roles of drought- and cold-inducible genes for galactinol synthase in stress tolerance in Arabidopsis thaliana. Plant J., 2002, 29, $417-$ 426.

49. Blum, A., Osmotic adjustment is a prime drought stress adaptive engine in support of plant production. Plant Cell Environ., 2017, 40(1), 4-10. 
50. Johnson, D. A., Asay, K. H., Tieszen, L. L., Ehleringer, J. R. and Jefferson, P. G., Carbon isotope discrimination: potential in screening cool-season grasses for water-limited environments. Crop Sci., 1990, 30, 338-343.

51. Wang, Y., Zhang, W., Song, L., Zou, J., Su, Z. and Wu, W., Transcriptome analyses show changes in gene expression to accompany pollen germination and tube growth in Arabidopsis. Plant Physiol., 2008, 148(3), 1201-1211.

52. Zamir, D., Pollen gene expression and selection: applications in plant breeding. In Isozymes in Plant Genetics and Breeding (eds Tanksley, S. D. and Orton, T. J.), Elsevier, New York, 1983, pp. 313-330.

53. Fukai, S. and Cooper, M., Development of drought-resistant cultivars using physio-morphological traits in rice. Field Crops Res., 1994, 40, 67-86.

54. Jongdee, B., Fuka, S. and Cooper, M., Leaf water potential and osmotic adjustment as physiological traits to improve drought tolerance in rice. Field Crops Res., 2002, 76(2-3), 153-163.

55. Nayyar, H., Accumulation of osmolytes and osmotic adjustment in water stressed wheat (Triticum aestivum) and maize (Zea mays) as affected by calcium and its antagonists. Environ. Exp. Bot., 2003, 50(3), 253-264.

56. Lacerda, C. F., Cambraia, J., Oliva, M. A. and Ruiz, H. A., Osmotic adjustment in roots and leaves of two sorghum genotypes under NaCl stress. Braz. J. Plant Physiol., 2003, 15(2), 113-118.

57. Chimenti, C. A., Marcantonio, M. and Hall, A. J., Divergent selection for osmotic adjustment results in improved drought tolerance in maize (Zea mays L.) in both early growth and flowering phases. Field Crops Res., 2006, 95(3), 305-315.

58. Pedersen, S., Simonsen, V. and Loeschcke, V., Overlap of gametophytic and sporophytic gene expression in barley. Theor. Appl. Genet., 1987, 75(1), 200-206.

59. Hormaza, J. I. and Herrero, M., Dynamics of pollen tube growth under different competition regimes. Sex. Plant Reprod., 1996, 9, $153-160$.

60. Liu, C., Liu, Y., Guo, K., Dayong, F. D., Li, G., Zheng, Y., Yu, L. and Yang, R., Effect of drought on pigments, osmotic adjustment and antioxidant enzymes in six woody plant species in karst habitats of south western China. Environ. Exp. Bot., 2011, 71, 174183

61. Sayfzadeh, S. and Rashidi, M., Response of antioxidant enzymes activities of sugar beet to drought stress. J. Agric. Biol. Sci., 2011, 6, 27-33.

62. Ji, X., Shiran, B., Wan, J., Lewis, D. C., Jenkins, C. L. and Condon, A. G., Importance of pre-anthesis anther sink strength for maintenance of grain number during reproductive stage water stress in wheat. Plant Cell Environ., 2010, 33, 926-942.

Received 3 August 2017; revised accepted 11 September 2018

doi: $10.18520 / \mathrm{cs} / \mathrm{v} 116 / \mathrm{i} 2 / 279-285$

\section{Synthesis and characterization of nano-selenium and its antibacterial response on some important human pathogens}

\section{Angamuthu Ananth, Venkidusamy Keerthika and Muthuswami Ruby Rajan*}

Department of Biology, The Gandhigram Rural Institute (Deemed to be University), Gandhigram 624 302, India

Synthesis of nano-selenium was achieved from sodium selenite by a simple precipitation method using the reducing power of ascorbic acid. The high-speed centrifuge was used to separate selenium nanoparticles from aqueous solution. The selenium nanoparticles were characterized by $U V-V$ is spectroscopy, $\mathrm{X}$-ray diffraction, Fourier transform-infrared spectroscopy (FT-IR), scanning electron microscopy, energy dispersive $X$-ray analysis and transmission electron microscope. Presence of various functional groups responsible for the production and stability of the nanoparticles was confirmed by FT-IR. Some of the important human pathogens like Staphylococcus aureus, Escherichia coli and Pseudomonas aeruginosa were used for examining the antibacterial response of selinium nanoparticles. Results of this study demonstrate that synthesized selenium nanoparticles exhibit a spherical shape with average diameter range between 15 and $18 \mathrm{~nm}$. They can be used as an antibacterial agent and also in medicinal applications for the treatment of humans with certain bacterial diseases.

Keywords: Antibacterial activity, characterization, human pathogens, synthesis, selenium nanoparticles.

NANOTECHNOLOGY is able to observe, measure, manipulate and manufacture things at the nanometre scale ${ }^{1}$. Currently, many nanosubstances are produced with the help of this emanating technology which occupies an important place in scientific research. Chemical composition, size, shape and morphology of nanoparticles are dealt within the synthesis process which is considered as a vital step in nanotechnological research ${ }^{2}$. Due to the size of the nanoparticles, their properties accustomed to giving a larger surface area compared to the bulk material. Thus, materials made up in such a way will have atoms that have more contact with the external environment; whereas those which are considered as bulk hold the atoms closer to the centre ${ }^{3}$. Application of nanoparticles can be associated with many fields like medical, food industries, environmental studies, electronics production, energy generation and agriculture ${ }^{4}$.

The most commonly used nanoparticles which have wide applications are silver, gold, zinc, copper and iron.

*For correspondence. (e-mail: mrrrajanbio@gmail.com) 